\title{
Population aging and the rising cost of public pensions
}

John Bongaarts

Population Council

Follow this and additional works at: https://knowledgecommons.popcouncil.org/departments_sbsr-pgy

Part of the Demography, Population, and Ecology Commons, Gerontology Commons, International Public Health Commons, and the Labor Economics Commons

How does access to this work benefit you? Let us know!

\section{Recommended Citation}

Bongaarts, John. 2004. "Population aging and the rising cost of public pensions," Policy Research Division Working Paper no. 185. New York: Population Council. Version of record: https://doi.org/10.1111/ j.1728-4457.2004.00001.x 


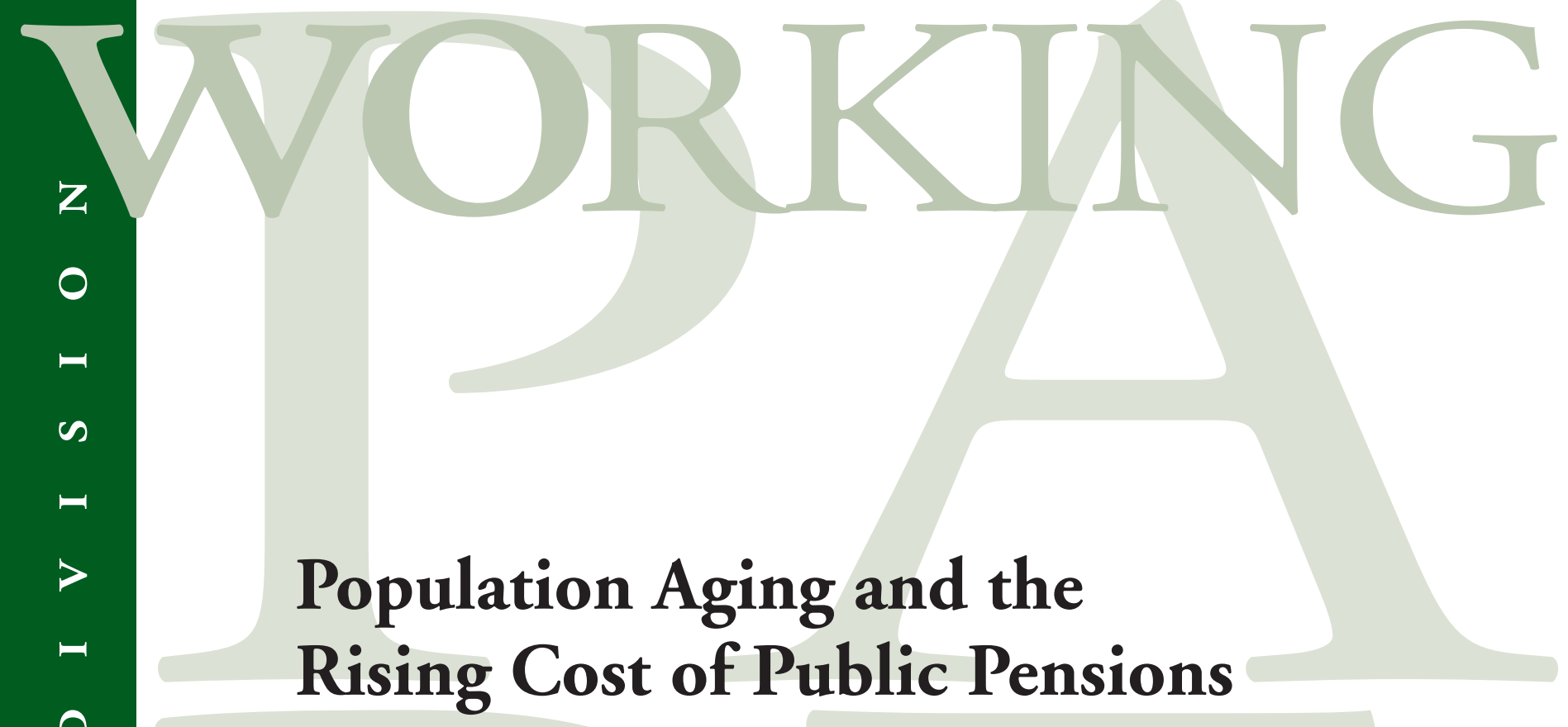

A

John Bongaarts

u

$\approx$

4

[I]

\%

다

电

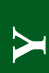

u

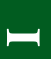

H

0

* 1 Population Council 


\title{
Population Aging and the Rising Cost of Public Pensions
}

\author{
John Bongaarts
}

John Bongaarts is Vice President, Policy Research Division, Population Council.

This material may not be reproduced without written permission from the author. For a list of Policy Research Division Working Papers, including those available for downloading in PDF format, see www.popcouncil.org/publications/wp/prd/rdwplist.html 


\begin{abstract}
Rapid population aging is raising concerns about the sustainability of public pension systems in high-income countries. The first part of this study identifies the four factors that determine trends in public pension expenditures: population aging, pension benefit levels, the mean age at retirement, and the labor force participation rate. The second part presents projections to 2050 of the impact of demographic trends on public pension expenditures in the absence of changes in pension benefits, labor force participation, and age at retirement. These projections demonstrate that current trends are unsustainable, because without reforms population aging will produce an unprecedented and harmful accumulation of public debt. A number of projection variants assess the potential impact of policy options aimed at improving the sustainability of public pension systems. Although the conventional responses are considered, particular attention is given to the demographic options of encouraging higher fertility and permitting more immigration. This analysis is illustrated with data from the seven largest OECD countries.
\end{abstract}


Since 1950, the median age of the population in the developed world-North America, Japan, Europe, and Australia/New Zealand-has increased from 29 years to 37 years, and it is expected to reach 45 years in 2050 (United Nations 2003). In contrast, the median age in the developing world-Africa, Asia (excluding Japan and Australia/New Zealand), and Latin America-stands at only 24 years. However, declines in fertility and mortality in these regions will inevitably also result in rapid aging, with the median age projected to reach 36 years in 2050. The developing world therefore will remain younger than the developed world, but the gap between them is closing. The present study focuses on the developed world.

Population aging has raised concerns about the sustainability of public pension systems (OECD 1998; World Bank 1994). In the past, the limited old-age support that existed was usually provided through informal family and community arrangements, but these have weakened nearly everywhere. Much of the support for the elderly in contemporary advanced societies is provided by public and private pensions and by government health care. These programs have been successful in closing the income gap between the elderly and the working-age populations, and poverty rates among the elderly have declined substantially. However, expenditures by widely implemented pay-as-you-go public pensions, which rely on transfers from younger to older generations, are becoming increasingly burdensome on the contributors and are eventually unsustainable as old-age "dependency rates" rise to high levels. A study from the International Monetary Fund suggests that failure to address these fiscal stresses in pay-as-you-go pension systems could inflict "serious macroeconomic damage, both on the domestic economy and, in the case of large industrial countries through international linkages, on the world economy" (Chand and Jaeger 1996: 1). The need to identify and implement reforms of public pension systems under these changing demographic conditions represents an urgent challenge for public policy.

The first part of this study examines cross-country variation in current levels of oldage dependency and public pension expenditures and benefits. The second part presents projections to 2050 of demographic trends and pension expenditures in the absence of changes in pension benefits or labor force participation. These projections provide the basis for assessing the potential impact of policy options aimed at improving the sustainability of social security systems. The main objective of this study is to demonstrate that current trends are unsustainable and to calculate sensitivities to policy options. Although the conventional responses are considered, particular attention is given to the demographic options of encouraging higher fertility and permitting more immigration. This analysis is illustrated with data from the seven largest OECD countries (Canada, France, Germany, Italy, Japan, the United Kingdom, and the United States) for which comparable demographic, labor force, and pension system statistics are available from the UN and the OECD (see Appendix for further details). These countries — often called the G7-are quite diverse in terms of their current and projected demographic conditions, retirement and labor force participation patterns, and the generosity of public pensions. 


\section{OLD-AGE DEPENDENCY}

The conventional old-age dependency ratio (ODR) is defined as the ratio of the population aged 65 years and older to the population aged 15-64. The inverse of this ratio is called the support ratio. For the developed world as a whole the old-age dependency ratio in 2000 stood at 0.25 , which implies a support ratio of four people of working age to every person aged 65+. The light gray bars in Figure 1 present results for the G7 countries. The dependency ratio ranges from about 0.25 in the four European countries and Japan to about 0.19 in the United States and Canada. The similarity of the values for the European countries and Japan reflects their broadly similar past levels of fertility, mortality, and migration. The United States and Canada have experienced somewhat higher levels of fertility and migration in recent decades and their ODRs are therefore lower.

The old-age dependency ratio is widely used in studies of population aging in part because it is easy to calculate and interpret, and data on levels and trends are available for all countries in the world from published estimates and projections of the United Nations (United Nations 2003). However, the ODR is flawed as an indicator of the demographic dimension of the "burden" of providing pensions in countries with pay-as-you-go systems for two reasons.

First, the number of pensioners usually exceeds the population aged 65 and older. Although 65 is the standard age at which retirees qualify for a full pension, reduced pensions are available at younger ages. The minimum age of eligibility for public pensions is 60 years in Canada, France, Germany, Japan, and the United Kingdom, 62 years in the United States, and 55 in Italy (Gruber and Wise 1999). For present purposes the number of pensioners is estimated as the population aged 65 and older plus anyone under age 65 who is retired and over this minimum age of eligibility ${ }^{1}$ (Disney and Johnson 2001). In 2000 the pensioner ratio (PR) — defined as the number of pensioners divided by the population aged $65+$ - ranged from 1.10 in the United States to 1.47 in Italy. The difference in the pensioner ratios of these two countries is largely due to the substantially higher average age at retirement in the United States than in Italy (64 vs. 58). In general, a higher age at retirement is associated with a lower proportion retired below age 65 and hence a lower pensioner ratio (see Figure 2).

Second, the number of workers is smaller than the population aged 15-64. Substantial proportions of the population of working age are not currently employed, either because of nonparticipation in the labor force or because of unemployment. In 2000 the employment ratio (ER) — defined as the number of employed persons divided by the population aged 1564-was lowest in Italy (0.55) and France (0.61) and highest in Japan (0.74) and the United States (0.76). Employment ratios are higher for males than for females; in 2000 male ERs averaged 0.77 for the $\mathrm{G} 7$ countries, and female ERs averaged 0.57. Although age at retirement is only one of several factors determining the employment ratio, the expected positive correlation between these variables is evident in Figure 2.

A more accurate indicator of the demographic burden of supporting the elderly is the ratio of pensioners to workers. The dark gray bars in Figure 1 show the pensioner/worker ratio in 2000 for each of the G7 countries. Values differ widely, from a low of 0.27 in the 
Figure 1 Old-age dependency ratio and pensioner per worker ratio in 2000

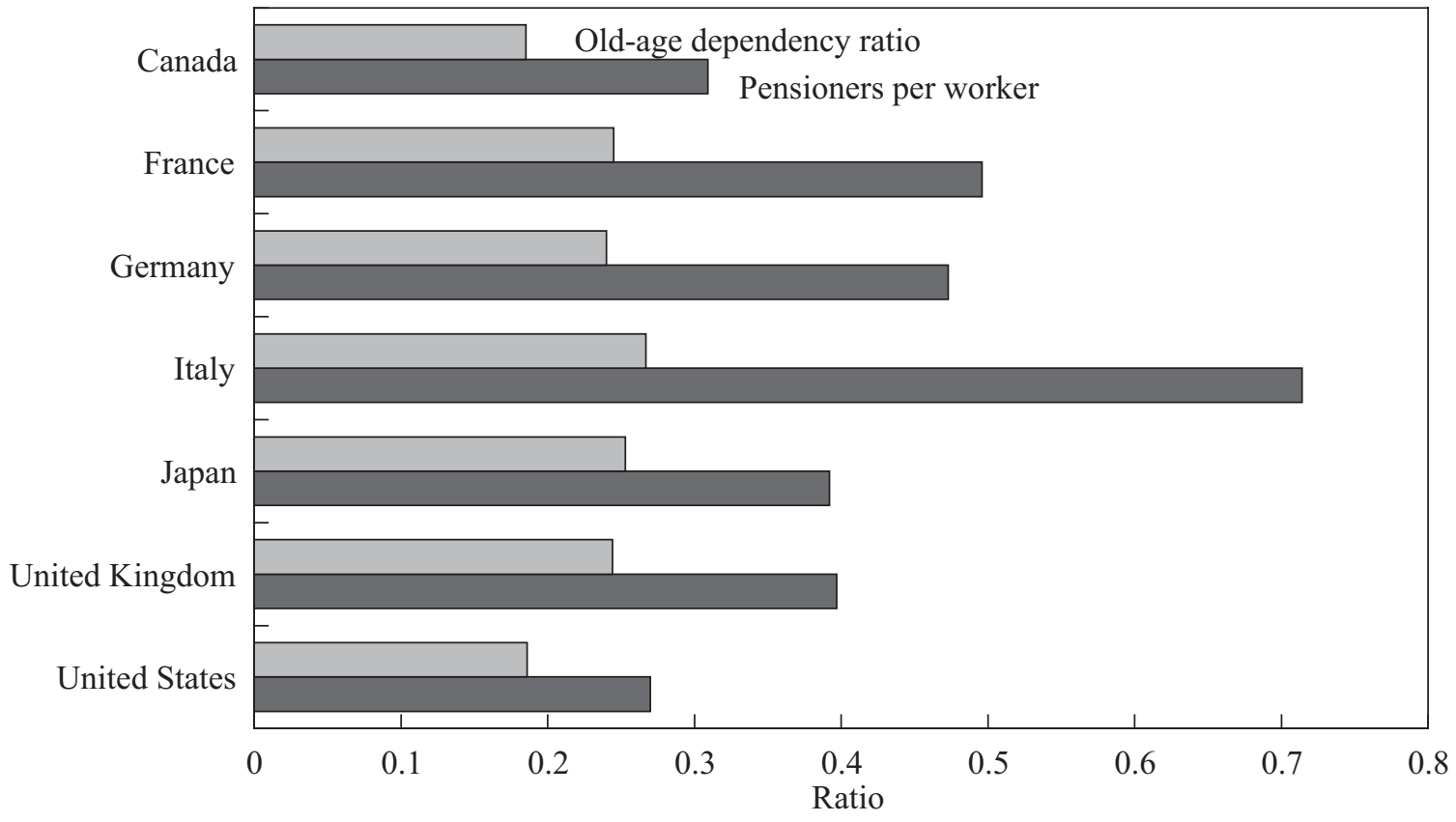

Note: The old-age dependency ratio equals the ratio of the population aged 65 years and older to the population aged 15-64. The number of pensioners is defined as the population aged 65 and older plus anyone under age 65 who is retired and over the minimum age of eligibility for a public pension.

Figure 2 Relationship between pensioner and employment ratios and mean age at retirement in 2000

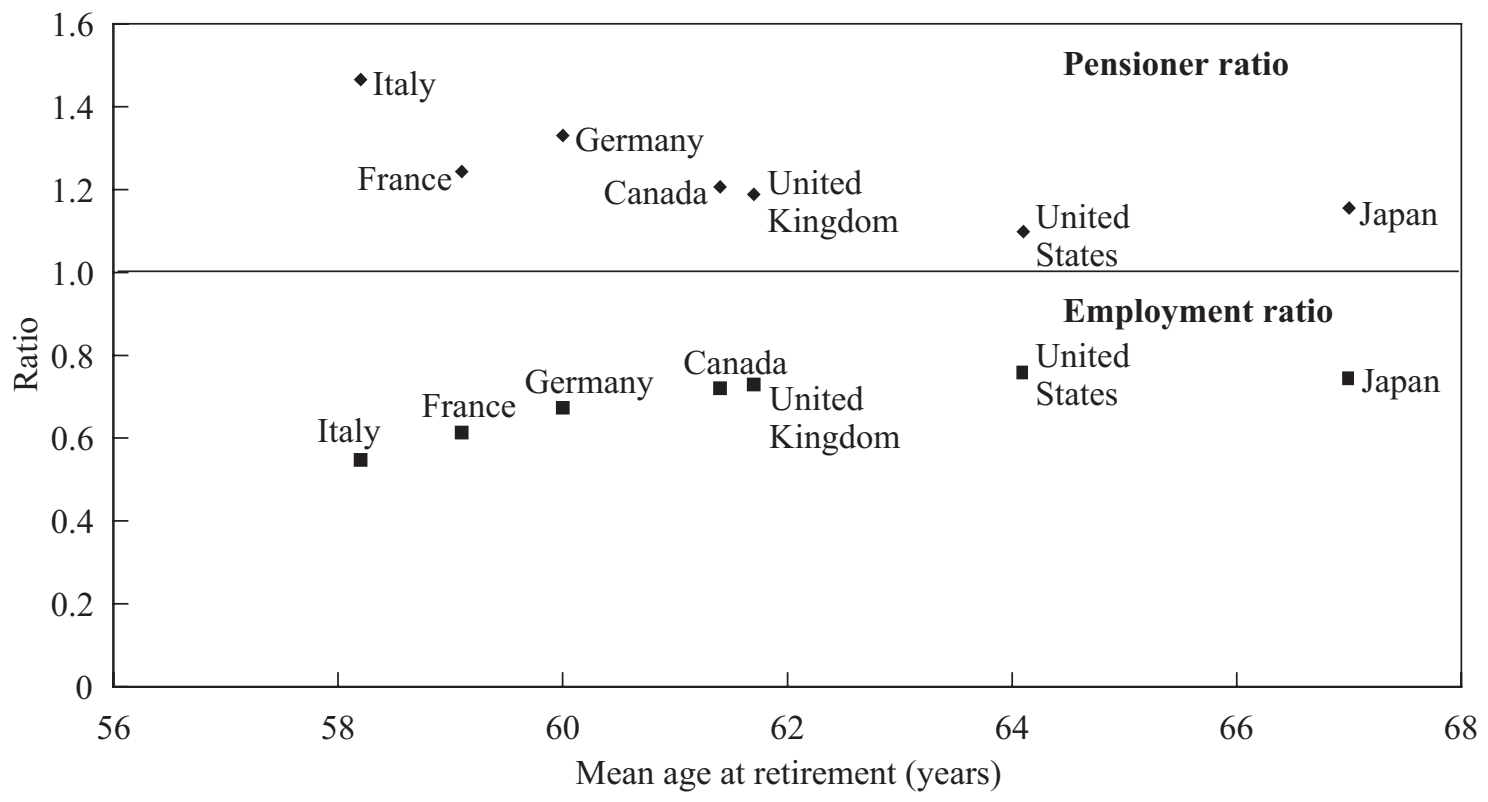

Note: The pensioner ratio equals the ratio of pensioners to the population aged 65 years and older. The employment ratio equals the number of employed persons divided by the population aged 15-64. The mean age at retirement is estimated with the method proposed by Latulippe (1996). 
United States to a high of 0.71 in Italy. This ratio is much larger than the conventional oldage dependency ratio in all seven countries, and in France and Italy the former is more than twice the latter.

The relationship between the pensioner/worker ratio (PWR) and the old-age dependency ratio (ODR) is summarized as

$$
\mathrm{PWR}=\mathrm{ODR} \times \mathrm{PR} / \mathrm{ER}
$$

The pensioner/worker ratio is directly related to the old-age dependency ratio and the pensioner ratio, but is inversely related to the employment ratio. For example, the highest pensioner/worker ratio value of 0.71 is observed in Italy, a country that also has the highest values for the old-age dependency ratio (0.27) and the pensioner ratio (1.47) and the lowest employment level $(E R=0.55)$ among the $\mathrm{G} 7$ countries. In contrast, the lowest pensioner/ worker ratio of 0.27 is observed in the United States, which has the second lowest old-age dependency ratio (0.19), the lowest pensioner ratio (1.10), and the highest employment ratio (0.76). The pensioner/worker ratio is one of the key determinants of the overall level of expenditures on public pensions, as discussed next.

\section{PENSION EXPENDITURES AND BENEFITS}

The main objective of mandatory national public pension systems is to protect people from steep declines in income after retirement from the labor force. This objective has now largely been achieved in OECD countries, where people over age 65 typically have a disposable income that, on average, corresponds to 70 to 80 percent of the income of people in the later working ages below age 65 (OECD 2001a). This estimate is based on income from all sources (public and private pensions, savings, and earnings) and holds even though the generosity and distributive nature of public pension systems varies considerably among countries. ${ }^{2}$ The success of these programs has been achieved in part by providing increasing levels of benefits over the past few decades. The expansion of individual benefits together with declining age at retirement and the aging of populations has resulted in a rapid rise in the overall cost of public pension systems.

The level of expenditures on public pensions is measured here as the pension expenditure ratio, PER, calculated as current total annual spending on public pensions divided by current total pre-tax annual earnings of workers (see Appendix for source of data). Expenditures include all old-age public pension spending as well as survivor benefits and minimum social assistance pensions (OECD 2001b; Dang et al. 2001). Earnings include wages, salaries, and self-employed income. ${ }^{3}$ In pay-as-you-go pension systems, the pension expenditure ratio is close to the social public pension tax or contribution rate; but in some cases total annual contributions exceed expenditures, resulting in a temporary surplus that accumulates as a reserve against future liabilities (e.g., in the United States). ${ }^{4}$ In other countries contributions fall short of pension spending, with the deficit being covered from general government revenue (e.g., in France, Germany, and Italy). 
Table 1 Estimates of public pension expenditure, benefit, old-age dependency, pensioner, employment, and pensioner per worker ratios in 2000

\begin{tabular}{lcccccc}
\hline & $\begin{array}{c}\text { Public pension } \\
\text { expenditure } \\
\text { ratio }\end{array}$ & $\begin{array}{c}\text { Benefit } \\
\text { ratio } \\
\text { PER }\end{array}$ & $\begin{array}{c}\text { BR } \\
\text { dependency } \\
\text { ratio } \\
\text { ODR }\end{array}$ & $\begin{array}{c}\text { Pensioner } \\
\text { ratio } \\
\text { PR }\end{array}$ & $\begin{array}{c}\text { Employ- } \\
\text { ment } \\
\text { ratio } \\
\text { ER }\end{array}$ & $\begin{array}{c}\text { Pensioner } \\
\text { per worker } \\
\text { ratio }\end{array}$ \\
PWR \\
\hline United Kingdom & 0.08 & 0.20 & 0.24 & 1.19 & 0.73 & 0.40 \\
United States & 0.08 & 0.31 & 0.19 & 1.10 & 0.76 & 0.27 \\
Canada & 0.10 & 0.33 & 0.18 & 1.21 & 0.72 & 0.31 \\
Japan & 0.14 & 0.36 & $\mathbf{0 . 2 5}$ & 1.16 & 0.74 & 0.39 \\
Germany & $\mathbf{0 . 2 4}$ & $\mathbf{0 . 5 1}$ & 0.24 & $\mathbf{1 . 3 3}$ & $\mathbf{0 . 6 8}$ & $\mathbf{0 . 4 8}$ \\
France & $\mathbf{0 . 2 9}$ & $\mathbf{0 . 5 8}$ & $\mathbf{0 . 2 4}$ & $\mathbf{1 . 2 5}$ & $\mathbf{0 . 6 1}$ & $\mathbf{0 . 5 0}$ \\
Italy & $\mathbf{0 . 3 5}$ & $\mathbf{0 . 4 9}$ & $\mathbf{0 . 2 7}$ & $\mathbf{1 . 4 7}$ & $\mathbf{0 . 5 5}$ & $\mathbf{0 . 7 1}$ \\
\hline
\end{tabular}

Note: Bold numerals indicate the three highest values for each ratio, except for ER.

PER equals the ratio of public pension expenditures to total pre-tax annual earnings of workers. BR equals the ratio of the average public pension benefits per pensioner to average earnings per worker. ODR equals the ratio of the population aged 65 years and older to the population aged 15-64. PR equals the ratio of pensioners (the population aged 65 and older plus anyone under age 65 who is retired and over the minimum age of eligibility for a public pension) to the population aged 65 years and older. ER equals the proportion of the population aged 15-64 that is employed. PWR equals the ratio of pensioners to workers.

Source: See Appendix.

Table 1 presents the public pension expenditure ratio in 2000 for the $\mathrm{G} 7$ countries. Pension expenditures amount to 10 percent or less of earnings in Canada (10 percent), the United Kingdom ( 8 percent), and the United States ( 8 percent), but they equal about one quarter of earnings in France (29 percent) and Germany (24 percent), and they slightly exceed one third of earnings in Italy (35 percent). This large variation among countries in expenditures is in part explained by variations in benefit levels.

The public pension benefit level is measured as the benefit ratio (BR), which equals the average public pension (per pensioner) divided by the average earnings (per worker). ${ }^{5}$ Estimates of the benefit ratio are presented in the second column of Table 1. Average public pension benefits are most generous in France, Germany, and Italy, where they equal or exceed half of average earnings. Benefits are lower in Canada, Japan, and the United States at only about a third of average earnings, and they are least generous in the United Kingdom at one fifth of average earnings. In interpreting these estimates it is important to note the following about the benefit ratio:

- No adjustments are made for taxes on earnings and pensions. ${ }^{6}$ Average tax rates are higher on earnings of workers than on the income of retirees because incomes of workers are on average higher than those of retirees and pensions often receive favorable tax treat- 
ment. Furthermore, retirees do not make pension contributions. As a result, the after-tax (net) benefit ratio is substantially higher than the (gross) benefit ratio presented here (Disney and Johnson 2001). Unfortunately, estimates of levels and trends in taxes are not readily available.

- Many retirees have sources of income other than public pensions, including corporate pensions and savings. The proportion of all income that is provided by these other sources tends to be highest in countries in which public pensions are least generous. As a result, the total income from all sources varies much less among countries than does the level of public pension benefits. Generous public pensions seem to "crowd out" private provisions (Disney and Johnson 2001).

- Countries differ widely not only in the average benefit but also in the distribution of pensions among retirees (OECD 2001a). In the United States, the United Kingdom, and Canada, where public benefit ratios are relatively low, public pension replacement rates are substantially higher for workers with low than with high earnings. In contrast, in countries with the most generous public pensions (France, Germany, and Italy) replacement rates are high regardless of individual earnings.

The public pension expenditure ratio equals the product of the benefit ratio and the number of pensioners per worker:

$$
\mathrm{PER}=\mathrm{BR} \times \mathrm{PWR} \text {. }
$$

Figure 3 plots the country-specific relationships between the public benefit ratio and the pensioner/worker ratio. Various combinations of the benefit ratio and the number of pensioners per worker can produce the same value of the expenditure ratio. For example, the public expenditure ratio in the United States and the United Kingdom is very similar at 0.08 , but the benefit ratio is substantially higher in the United States than in the United Kingdom ( 0.31 vs. 0.20$)$ while the reverse is true for the pensioner/worker ratio $(0.27$ vs. 0.40$)$.

Countries with high public benefit ratios tend to have a high number of pensioners per worker (see Figure 3). This association is likely to be the result of two-way causation. A larger number of pensioners provides the voting power to ensure that public benefits are high, and high public benefits induce workers to retire early.

Substitution of the equation for PWR derived in the preceding section gives

$$
\mathrm{PER}=\mathrm{BR} \times \mathrm{ODR} \times \mathrm{PR} / \mathrm{ER} .
$$

This result implies that the public expenditure ratio is determined by four factors: the benefit, old-age dependency, pensioner, and employment ratios. ${ }^{7}$ Table 1 presents estimates of these factors with countries ordered from lowest to highest expenditure ratio (bold indicates the three highest values for each ratio except for the employment ratio). As noted, the highest expenditure ratio (0.35) is found in Italy. This value is the result of Italy's having the highest old-age dependency and pensioner ratios, the third-highest public benefit ratio, and 
Figure 3 Relationship between the public pension benefit ratio and the pensioner/worker ratio

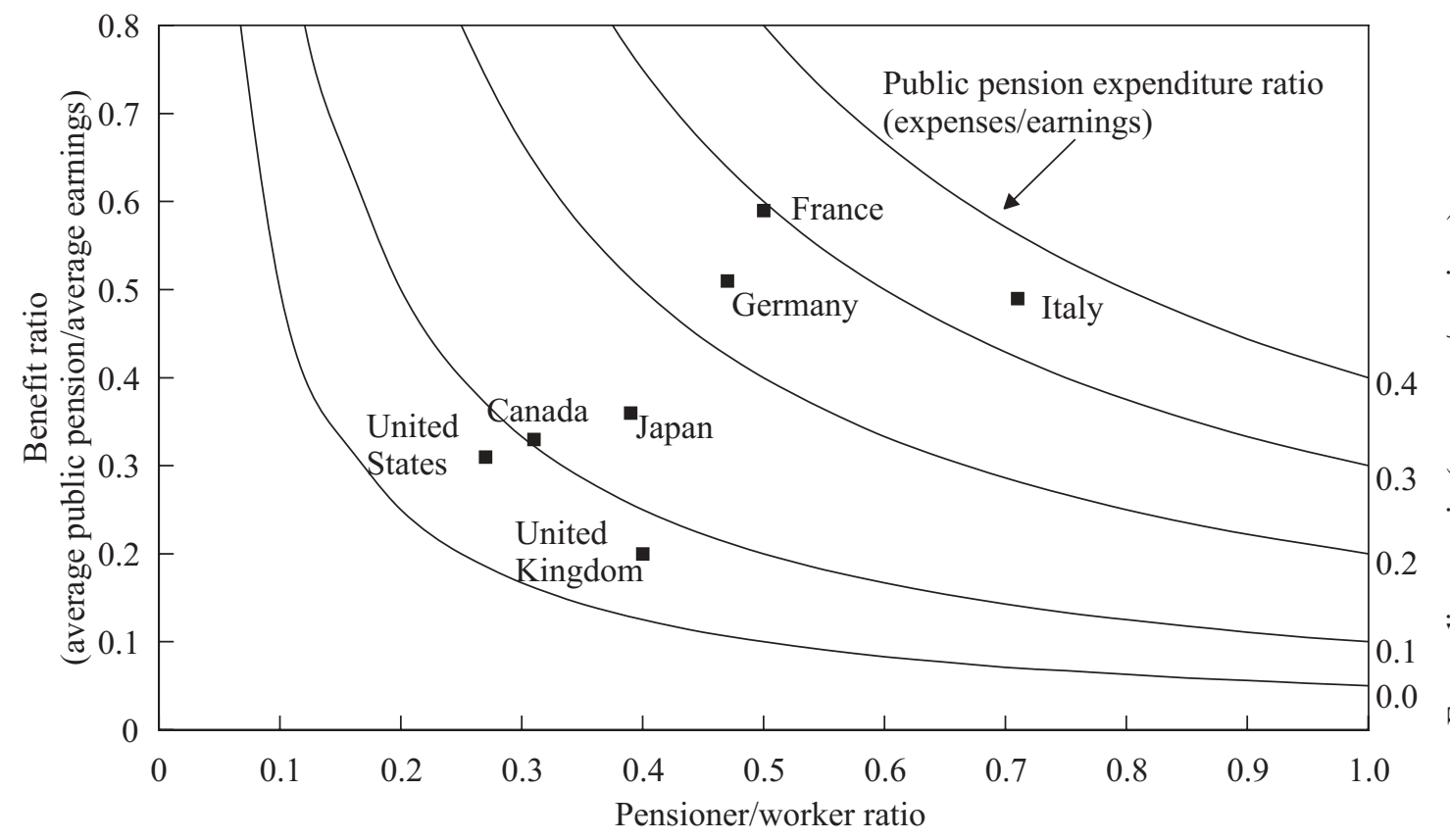

Figure 4 Old-age dependency ratio, estimates 1970-2000 and projections 2000-2050

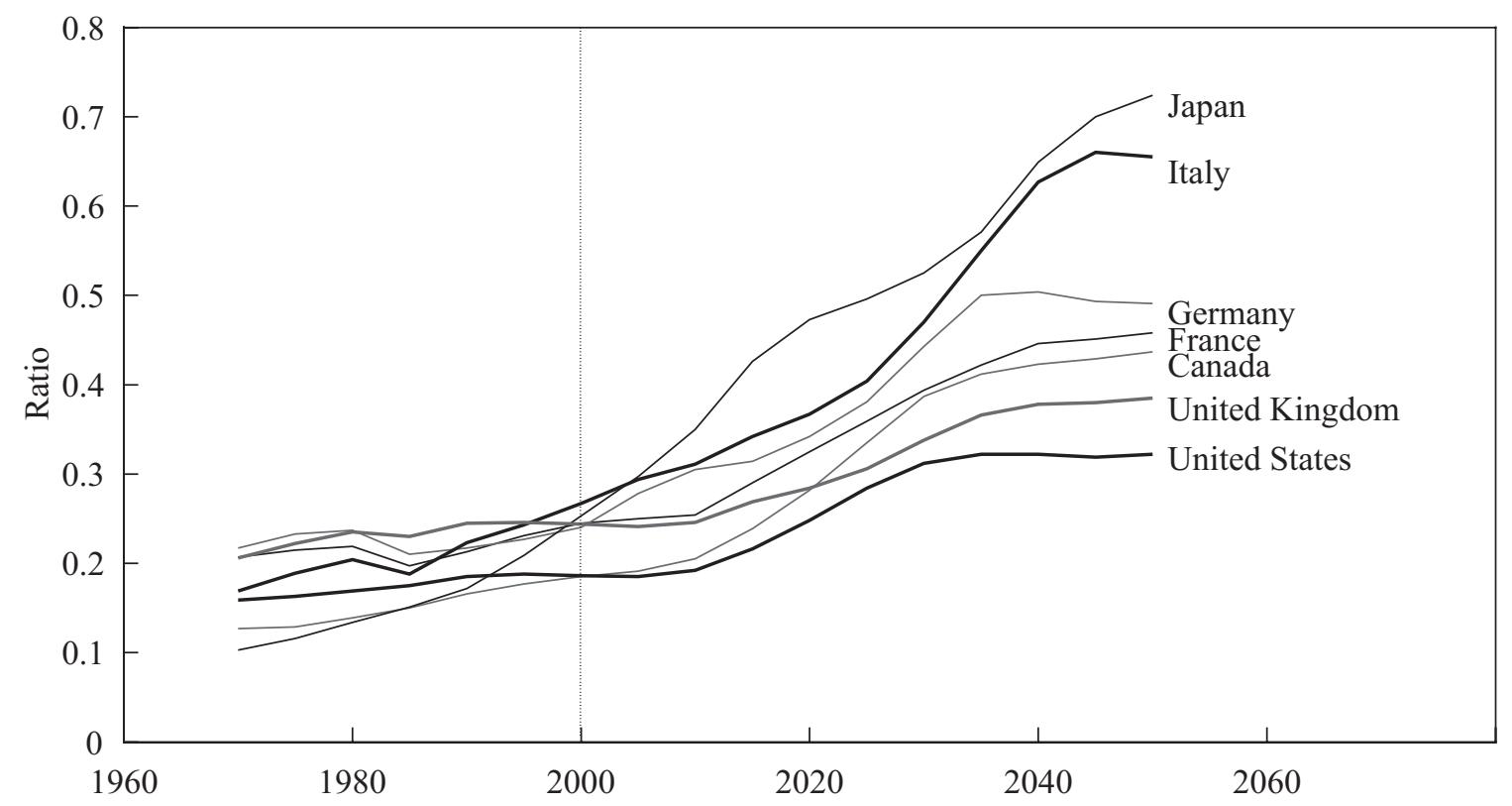

Note: The old-age dependency ratio equals the ratio of the population aged 65 years and older to the population aged $15-64$.

Source: UN (2003). 
the lowest employment ratio. The United Kingdom has the lowest expenditure ratio, which is the result of its very low public benefit ratio, below-average value for the pensioner ratio, and third-highest employment ratio.

\section{ProjeCtions of PUbliC PENSION EXPENDITURES:}

\section{THE REFERENCE SCENARIO}

The construction of a reference projection is the first step in the analysis of future trends in public pension expenditures. The purpose of this reference projection is not to forecast the most likely trend in public pension expenditures and related demographic factors, but rather to serve as a simple benchmark against which alternative projections can be assessed.

The reference projections of annual public pension expenditure levels from 2000 to 2050 are based on the following assumptions regarding the four factors that determine the expenditure ratio.

\section{Old-age dependency ratio}

Future population trends are taken from the medium variant of the UN population projections (United Nations 2003). These projections are based on a number of assumptions about future levels of fertility, mortality, and migration. The details are specific to individual countries, but in general the UN assumes that mortality improvements will continue, that fertility will rise appreciably in countries with very low fertility, and that the flow of migration will remain close to current levels. Figure 4 summarizes these projections. Trends are not linear over the next 50 years. During the next decade the pace of aging is expected to be modest in France, the United States, the United Kingdom, and Canada, but quite rapid in Italy, Germany, and, in particular, Japan. By 2010 Japan's oldage dependency ratio is likely to reach about 0.35 , double the level of 0.17 observed in 1990. After 2010 the pace of aging is high in all seven countries, resulting in large increases in the old-age dependency ratios by 2050. The most rapid aging will occur in Japan and Italy, which are expected to reach old-age dependency ratios around 0.7 , nearly triple the level of about 0.25 in 2000. Even in the countries with the least amount of aging, the old-age dependency ratio is expected to increase by more than half: from 0.19 to 0.32 in the United States, from 0.24 to 0.38 in the United Kingdom, and from 0.18 to 0.43 in Canada. The range of values of the projected old-age dependency ratio in 2050, from 0.32 for the United States to 0.72 in Japan, is much wider than in 2000. This divergence of trends is a result of differences in the projected levels and trends in fertility, mortality, and migration and in the current population age structure. Differences in average levels of fertility and migration during the projection interval appear to be particularly crucial. The two countries with the lowest projected levels of future fertility and migration (Italy and Japan) are expected to have the highest old-age dependency ratios in 2050. In contrast, the old-age dependency ratio in 2050 is much smaller in the United States, the country with 
one of the highest projected fertility and migration levels. The role of variation in fertility and migration in determining future levels of old-age dependency will be examined in greater detail below.

\section{Employment ratio}

Figure 5 plots estimates of the employment ratio from 1970 to 2000, based on available OECD data (see Appendix). These trends are determined by a multiplicity of factors, including rising female labor force participation and rising age at entry into the labor force as well as earlier retirement. These partially offsetting factors have resulted in modest increases in the employment ratio where the rise in female employment has dominated (e.g., in Canada, Japan, and the United States), or in modest declines in the employment ratio where later entry into the labor force and declining age at retirement have dominated (e.g., in France). In the reference projection to 2050, I assume that age- and sex-specific employment rates will remain invariant at levels observed in 2000 for the duration of the projection. The future trends in the employment ratios implied by this assumption are also plotted in Figure 5. Only minor changes in the ER are projected and these future changes are entirely due to future changes in the age composition of the population of working age.

\section{Pensioner ratio}

As shown in Figure 6 the pensioner ratio (estimated with the procedure described earlier) changed relatively little between 1970 to 2000. Some countries (e.g., France and Germany) have experienced slight increases and others (e.g., Canada, Japan, the United Kingdom, and the United States) small declines. These changes are the net result of trends in three underlying factors: the age at retirement, labor force participation (which affects the pensioner ratio even if the retirement age is unchanged), ${ }^{8}$ and a changing population age structure. For purposes of the reference projection, I assume that the age and sex pattern of employment remains constant from 2000 to 2050, which implies a fixed age at retirement. Although age at retirement has declined since 1970, this trend seems to have run its course with little change in retirement age during the 1990s. Any changes in the pensioner ratio projected for the next half century are therefore due solely to future changes in the age structure of the population of elderly.

\section{Benefit ratio}

Throughout the reference projection I assume that this ratio remains constant at 2000 country-specific levels. This is equivalent to indexing pensions to wages.

In sum, the reference projection reflects fixed employment and retirement patterns by age and sex, and no change in the benefit ratio. The projections for expenditures are therefore driven by demographic trends, mostly the rise in the old-age dependency ratio but also minor effects of the changing age structure on the pensioner and employment ratios. 
Figure 5 Employment ratios, estimates 1970-2000 and projections 2000-2050

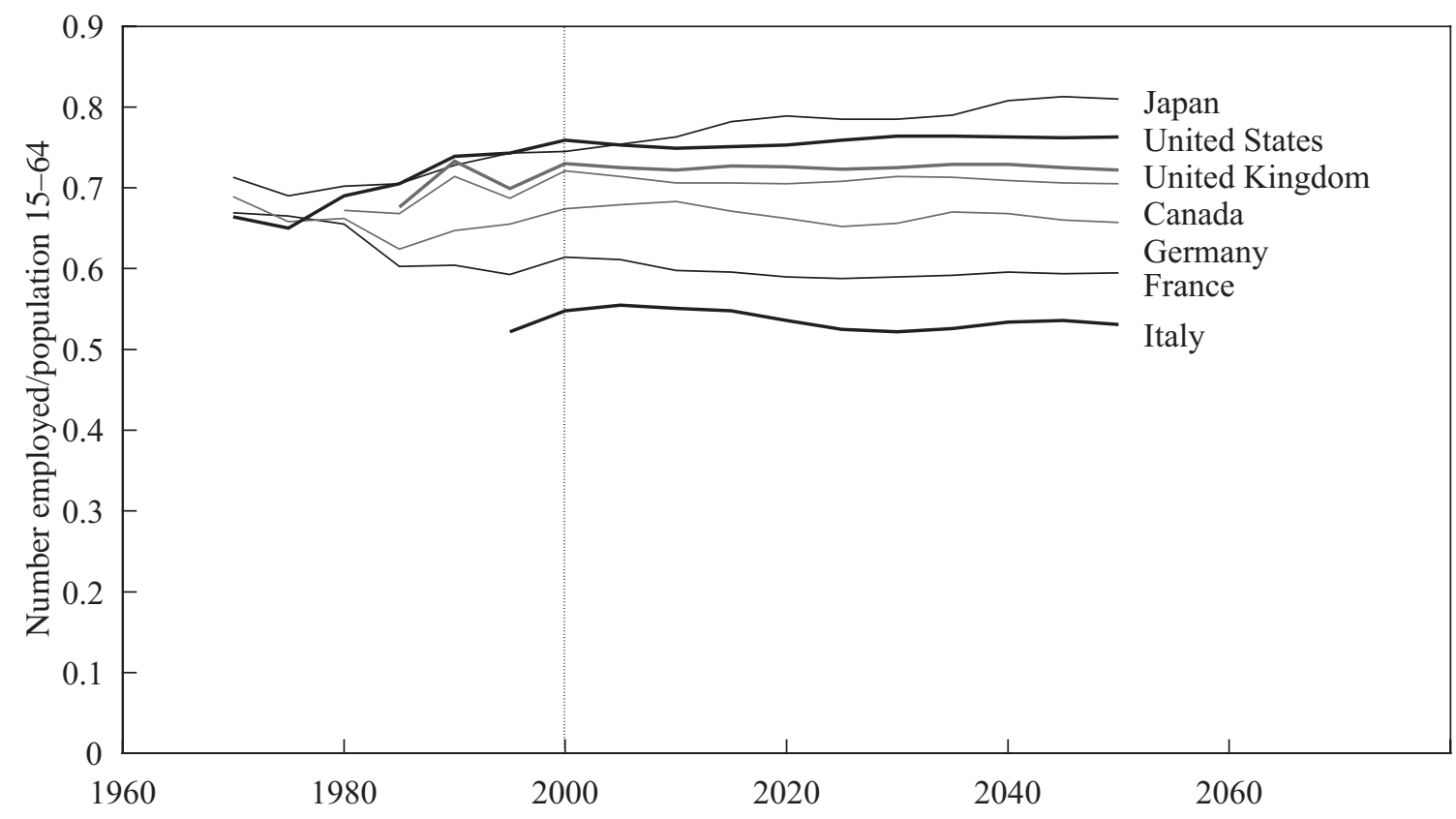

Source: Up to 2000 OECD (see Appendix); 2000-50 see text.

Figure 6 Pensioner ratio, estimates 1970-2000 and projections 2000-2050

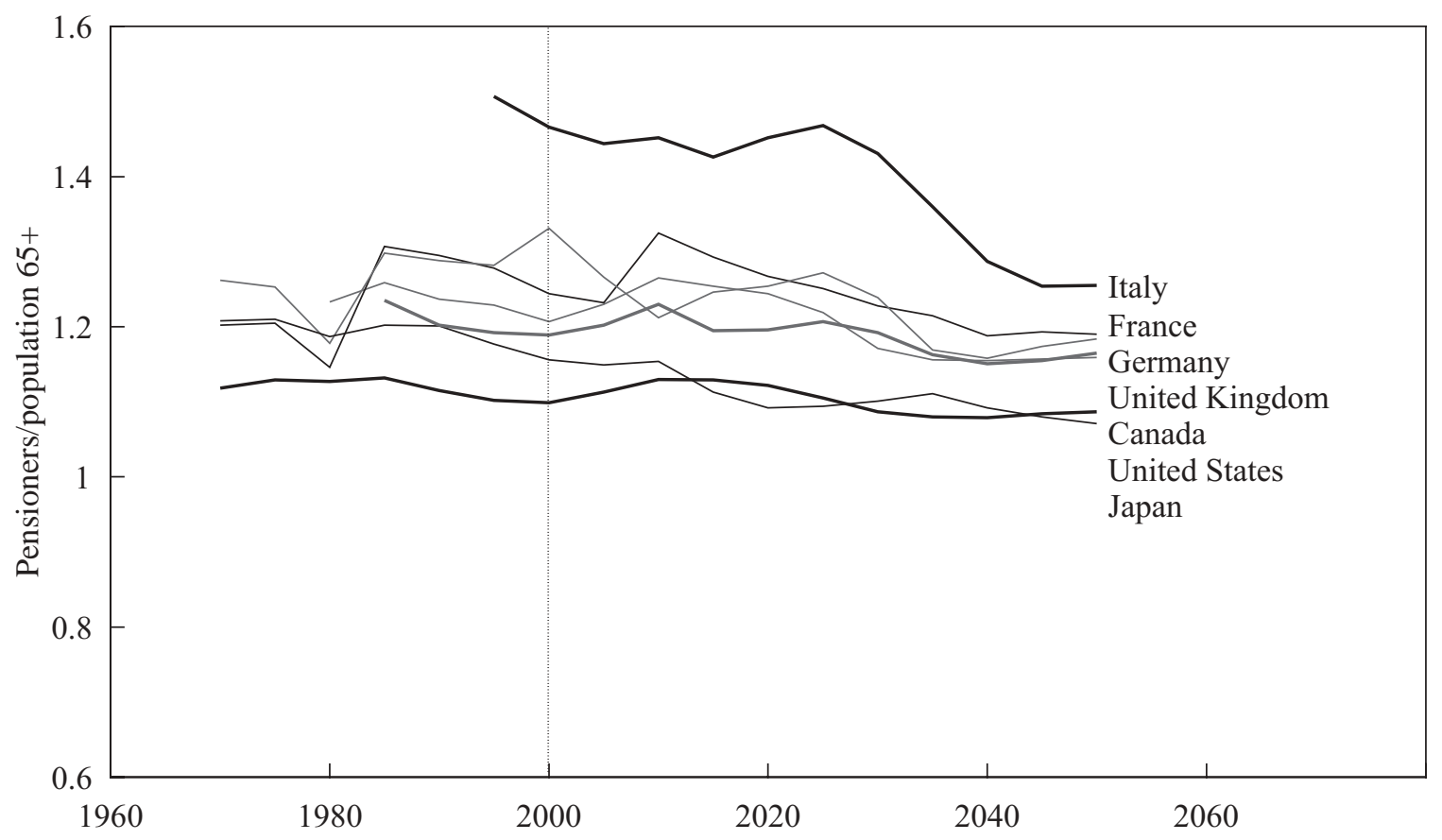

Source: Up to 2000 OECD (see Appendix); 2000-50 see text. 
Figure 7 Pensioners per worker, estimates 1970-2000 and projections 2000-2050

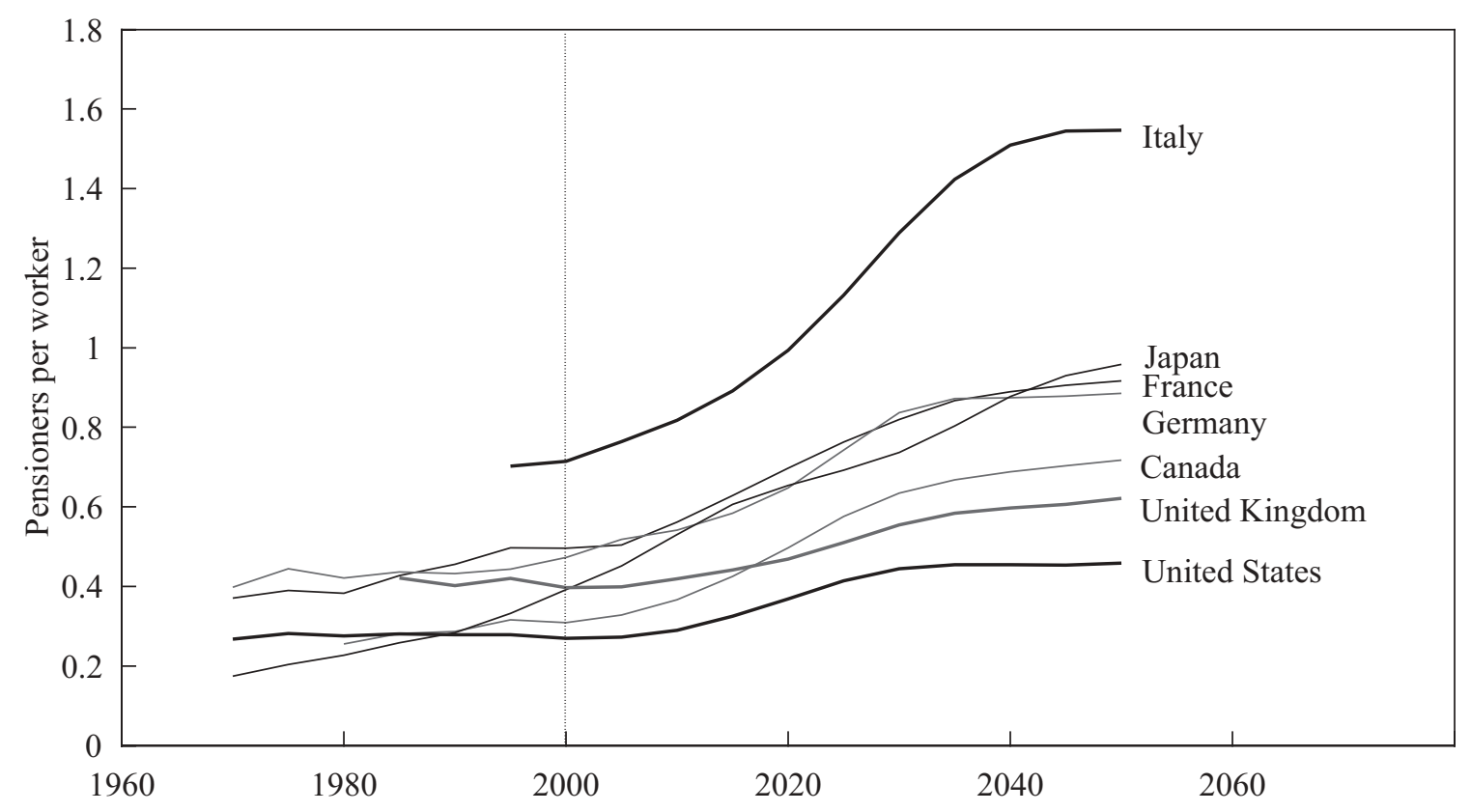

Source: Calculated from estimates shown in Figures 4, 5, and 6.

Figure 8 Public pension expenditures as a percent of earnings, baseline projections 2000-2050

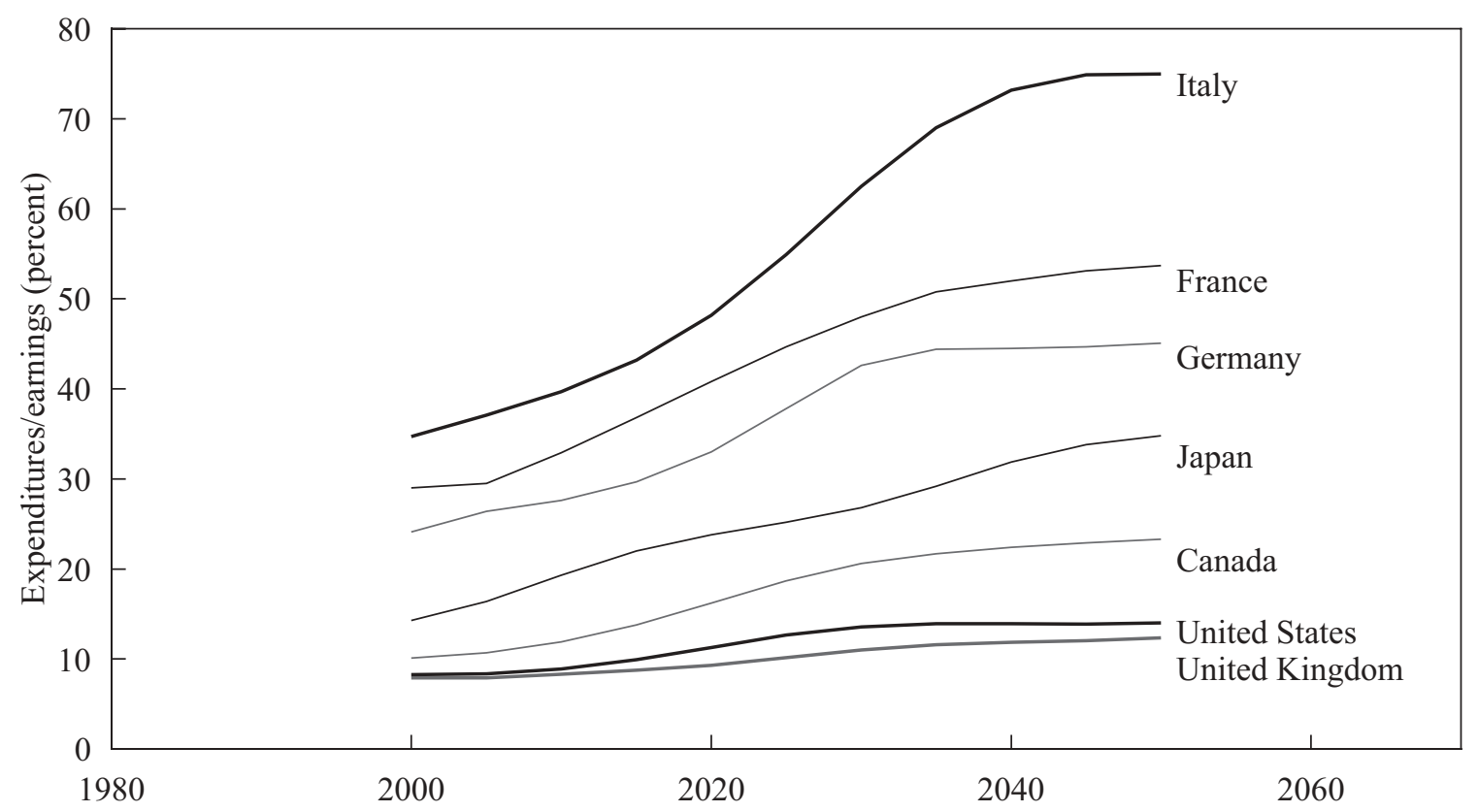

Source: Calculated from estimates in Figure 7. Estimates for 2000 from OECD (2001b) and Dang et al. (2001). See Appendix. 
The reference projection does not attempt to incorporate effects of recent policy changes that are intended to reduce future deficits in pension systems. ${ }^{9}$

The reference projections of the pensioner/worker ratio are summarized in Figure 7. As one would expect from the upward trends in the old-age dependency ratio, the number of pensioners per worker rises sharply by 2050 in all countries. In Italy the number of pensioners is expected to exceed substantially the number of workers by 2050 , with the PWR reaching 1.55 . In 2050, Japan is projected to have an old-age dependency ratio similar to that of Italy, yet its pensioner/worker ratio remains lower (0.96) owing to a later age at retirement in Japan. Even in the United States, the country with the least rapid population aging, the pensioner/worker ratio is projected to reach 0.46 in 2050 , a substantial 70 percent increase from 0.27 in 2000 .

The related public pension expenditure projections are presented in Figure 8. Since benefit ratios are assumed to remain at levels observed in 2000, the projection for the expenditure ratio is proportional to the projected trend in the pensioner/worker ratio. Large increases in expenditures are expected in all seven countries. The largest rise is projected for Italy, where the expenditure ratio grows from 35 percent to 75 percent of earnings between 2000 and 2050. Smaller but still substantial increases are expected in the United States (from 8 to 14 percent of earnings) and the United Kingdom (from 8 to 12 percent). These trends are clearly unsustainable over the next few decades for Italy and other continental European countries, and even the smaller projected growth in expenditures in the United Kingdom and the United States is often considered problematic.

\section{POLICY OPTIONS}

Governments of major industrial countries are urgently considering pension reform with the strong endorsement of the IMF, OECD, and World Bank. Avoiding action is no longer a feasible option because an unprecedented and harmful accumulation of debt would then result. In the past, the rising cost of public pension benefits has often been covered by raising public pension tax rates. This revenue-enhancing approach has become unsustainable in many countries because contributions have reached very high levels and expenditure-reducing approaches are now given highest priority. ${ }^{10}$ Another reason for urgency is that legislative changes are usually made many years before they have a significant impact, to allow workers and retirees to adapt to the new policies.

A range of policy options are available to reduce or end the growth of public pension expenditures. These options can be divided into four groups corresponding to the four factors that determine public pension expenditures:

\section{Counteract population aging}

Since population aging is the main cause of the future deterioration of the fiscal balance of public pension systems, it is natural to consider ways to counteract aging as a partial solution. Two demographic options are available: 
Encourage higher fertility. Increasing fertility above projected levels raises the size of younger age groups relative to older age groups, thus reducing the old-age dependency ratio and the number of pensioners per worker. The size of this fertility effect is estimated with a set of alternative hypothetical "higher-fertility" projections in which half a birth per woman is added to the fertility trajectory in the reference projection. In the reference projections the average total fertility rates (TFRs) from 2000 to 2050 are assumed by the UN to be as follows: Canada (1.6), France (1.9), Germany (1.6), Italy (1.5), Japan (1.6), the United Kingdom (1.7), and the United States (2.0). (These projected rates are broadly similar to levels observed in the late 1990s, with small increases in Germany, Italy, and Japan.) ${ }^{11}$ Figure 9 compares estimates of the expenditure ratio in 2050 in the reference and higherfertility projections. As expected, the pension expenditure ratio is lower in the higherfertility than in the reference projections. For example, in Italy the reference scenario has an average TFR of 1.5 for 2000-2050 and a projected pension expenditure ratio of 0.75 in 2050. Raising fertility by 0.5 births per woman to 2.0 between 2000 and 2050 lowers the expense ratio to 0.59 in 2050 , a 20 percent reduction. Interestingly, the lines representing the results for each country in Figure 9 are close to parallel (note logarithmic scale on the vertical axis). This finding implies that a given absolute increase in fertility results in a proportional reduction in the expense ratio that is approximately the same for each country. Specifically, on average for each increase in fertility of 0.1 births per woman, the expenditure ratio in 2050 declines by 4 percent.

Permit more immigration. In contemporary developed countries the average age of immigrants is lower than that of the resident population. As a result, increasing the number of immigrants reduces both the average age of the population and the old-age dependency ratio (United Nations 2001). I estimate the size of this immigration effect with a set of hypothetical "higher-migration" projections in which the annual net migration rate in the reference projection is raised by 2.5 net migrants per 1,000 population. In the reference projections the average annual net migration rates for 2000 to 2050 are assumed by the UN to be as follows: Canada (4.7), France (1.2), Germany (2.6), Italy (1.2), Japan (0.4), the United Kingdom (2.2), and the United States (3.2). (These rates are broadly similar to levels observed in the late 1990s.) $)^{12}$ As shown in Figure 10, adding 2.5 per 1,000 to these migration rates reduces the expenditure ratio in 2050 in the higher-migration projection compared to the reference projection. For example, raising Japan's annual net migration rate from 0.4 to 2.9 per 1,000 cuts the expenditure ratio in 2050 from 0.35 to 0.29 . As was the case for the fertility variants, the parallel lines in Figure 10 imply that a given rise in the average migration rate reduces the pension expenditure ratio by roughly the same proportion. On average, an increase in the annual net migration rate of 1 per 1,000 population reduces the expenditure ratio in 2050 by 5 percent.

Although trends in population size are not the focus of this analysis, it is worth noting that the United Nations projects population declines between 2000 and 2050 in Germany (from 82 million to 79 million), Italy (from 58 to 45 million), and Japan (from 127 to 110 million). In the higher-fertility projection population size in 2050 is higher than in the 
Figure 9 Effect of an increase in the total fertility rate by 0.5 births per woman (2000-2050) on the pension expenditure ratio in 2050: Comparison of reference and higher-fertility projections

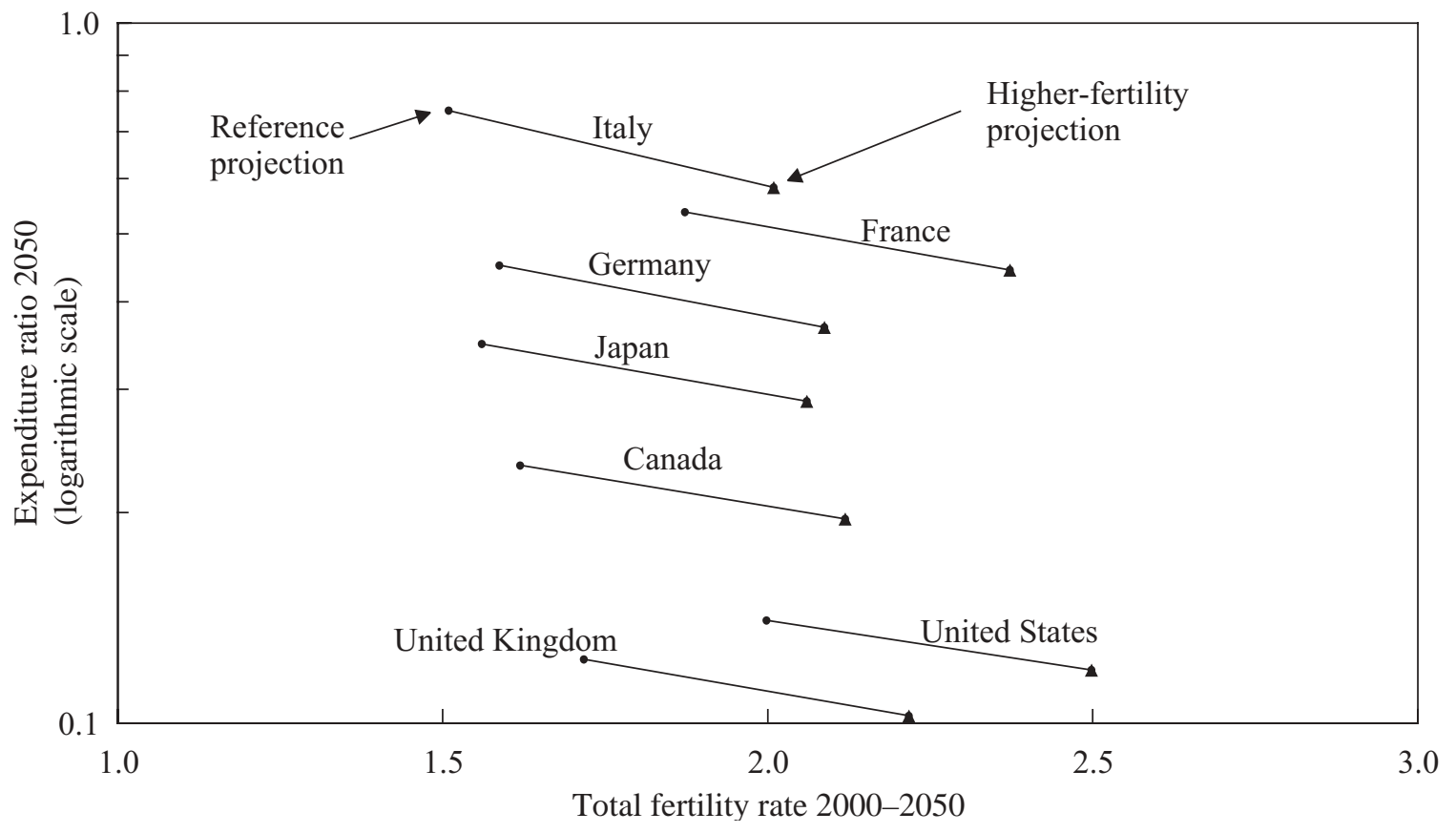

Figure 10 Effect of an increase in the annual net migration rate by 2.5 per 1,000 population (2000-2050) on the pension expenditure ratio in 2050: Comparison of reference and higher-migration projections

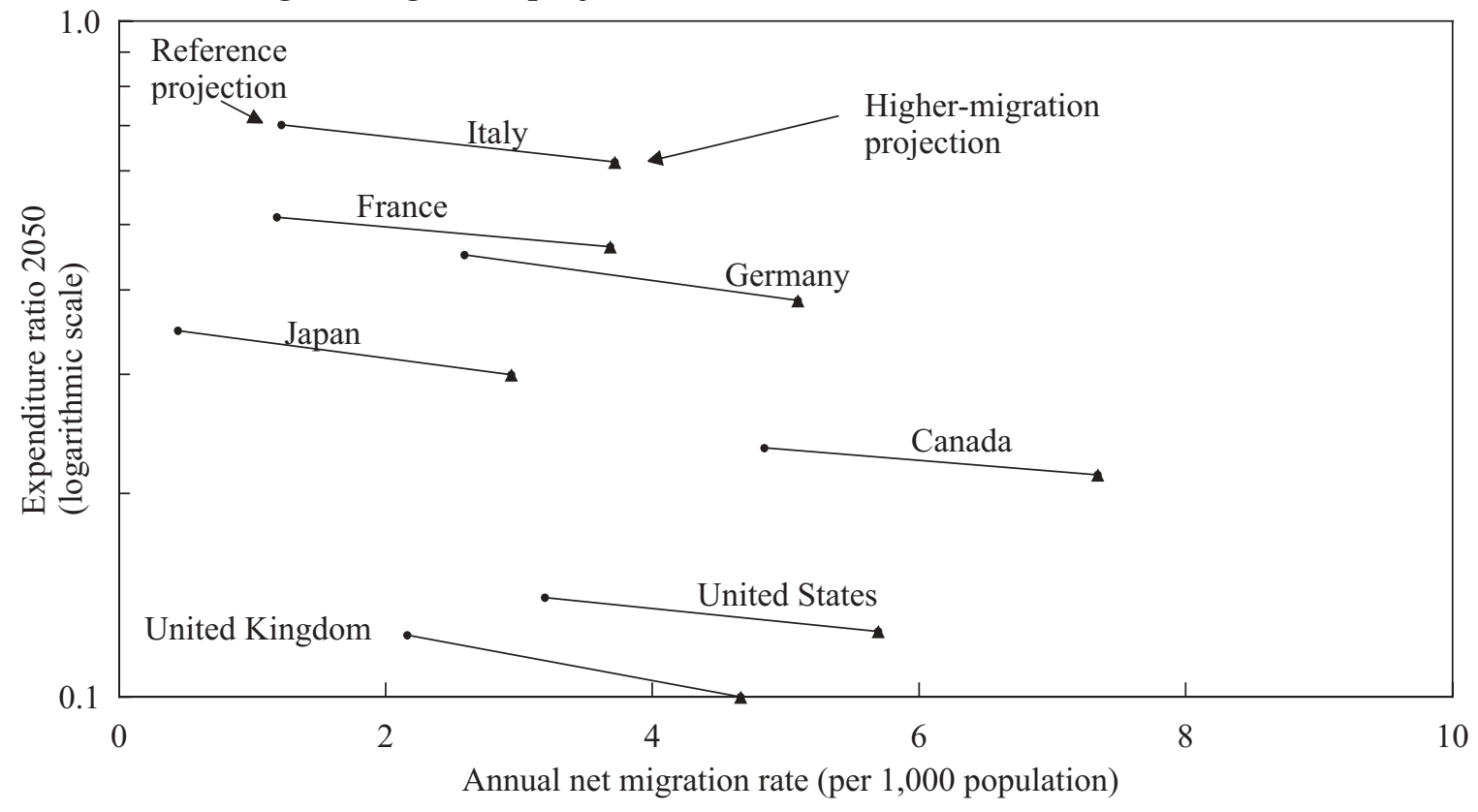


standard projection by 22 percent on average, with relatively little variation in this fertility effect among countries (range from 20 to 23 percent). Similarly, the higher-migration projection added 21 percent on average to the reference projection. An increase in fertility of half a birth per woman or an increase in the annual migration rate of 2.5 per 1,000 would therefore be more than sufficient to prevent the population declines expected in Germany and Japan, but Italy's population would still experience a small decline (by 4 percent with a rise in fertility and by 5 percent with a rise in migration).

\section{Increase labor force participation}

A substantial proportion of males and an even larger proportion of females between ages 15 and 64 are not currently employed. Any rise in the employment ratio would directly reduce the pensioner/worker ratio. A secondary effect of an increase in employment levels would be to reduce the pensioner ratio by raising the number of workers above the minimum age of pension eligibility. Future increases in labor force participation are most feasible in countries where it is relatively low on average or where the gap between males and females is large. For example, the overall employment ratio in Italy in 2000 is a relatively low 0.55 in part because of a large gap between male and female employment ratios ( 0.70 vs. 0.40$)$. If future female labor force participation were to rise to equal that of males, the overall employment ratio would increase from 0.55 to about 0.70 . This effect alone would cut the pensioner/worker ratio by 21 percent.

\section{Raise the age at retirement}

An increase in the age at retirement reduces the pensioner/worker ratio by simultaneously reducing the number of retirees and raising the number of workers. I simulate the total effect of such a shift in a set of hypothetical "later-retirement" projections in which five years are added to the age at retirement between 2000 and 2050 in equal increments. The results from this projection are presented in Figure 11. The proportional effects of a shift in retirement age are again approximately the same for the various countries. On average, a one-year increase in age at retirement reduces the pensioner/worker ratio in 2050 by 6 percent.

The trend in age at retirement over the past several decades has been downward for two main reasons (OECD 2002a; Gruber and Wise 1999). First, public and employerprovided pensions have become more generous and the average income of retirees is now not much below that of the average worker. Second, there is usually little incentive to continue working once a retiree qualifies for a pension because working an additional year implies paying additional taxes supporting the public pension scheme and forgoing a pension for that year with little or no compensatory increase in future pensions. Eliminating this disincentive to continue working may halt the decline in the age at retirement and will be essential to reversing this past trend. 
Figure 11 Effect of an increase in the retirement age by 5 years (2000-2050) on the expenditure ratio in 2050: Comparison of reference and later-retirement projections

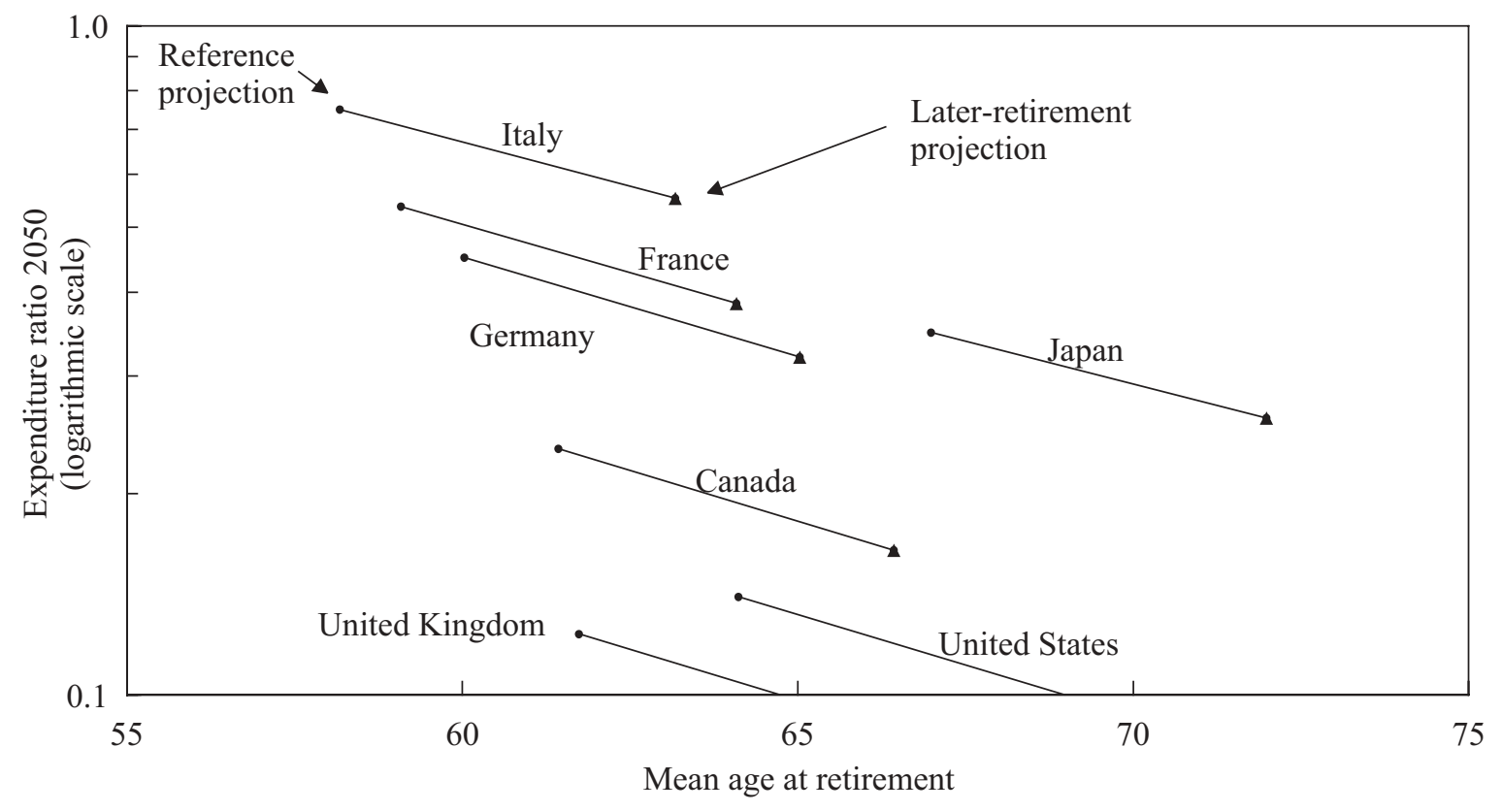




\section{Reduce public pension benefits}

Benefit levels are determined by rules and formulas that vary from country to country. Most countries have earnings-related pensions whose initial value at the time of retirement depends on the number of years worked and on the level of past earnings with adjustments for inflation. After retirement, pensions are adjusted annually for changes in the cost of living. Tax treatment of pensions also varies considerably among countries. Cuts in benefits can be achieved by changing any of these rules, regulations, and adjustments either for all pensioners or for selected subpopulations such as high-income groups. The effect of a reduction in the benefit ratio on the expenditure ratio is of course straightforward to estimate because any proportional decline in the former results in an equal proportional decline in the latter.

If these efforts to bring expenditures in line with contributions are not successful, two other options are available: increase taxes or accept a deficit and accumulate debt. Both alternatives are unattractive. Public pension taxes have been raised in the past, but there is strong resistance to further increases. This is especially true in countries where tax rates are already very high (Italy, France, Germany). It seems unwise, however, to rule out any further tax increases as a partial solution to reducing the projected fiscal deficits in countries such as the United States and the United Kingdom where these taxes are still relatively low.

Table 2 compares the effects of the different options by providing an estimate of the change in each factor that is required to bring about a 10 percent proportional decline in pension expenditures in 2050. To prevent the large increases in expenditures expected in the reference scenario, countries can adopt one or more of these options. Relying on any one option alone will probably not be sufficient. For example, to prevent the expenditure ratio from rising after 2000, Italy could choose to cut benefits only. But the required cuts would be very large, reaching 55 percent by 2050. This is likely to be politically difficult to implement, and the government must therefore also consider other options. The most likely outcome in most OECD countries is that the large increases in expendi-

Table 2 Change required in demographic, labor force, retirement, and benefit variables to reduce pension expenditures by 10 percent in 2050 (G7 average)

\begin{tabular}{ll}
\hline Policy variable & Change required \\
\hline Fertility (2000-2050) & Increase of 0.27 births per woman \\
Net migration rate (2000-2050) & Increase of 1.8 net migrants per 1,000 population \\
Employment ratio (2050) & Increase of 9 percent ${ }^{\mathrm{a}}$ \\
Mean age at retirement (2050) & Increase of 1.6 years \\
Pension benefits (2050) & Reduction of 10 percent \\
\hline
\end{tabular}

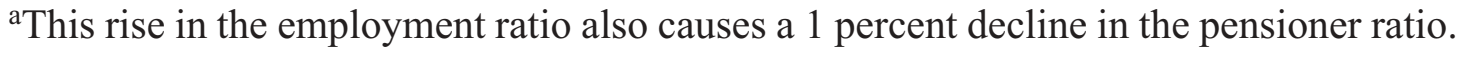


tures expected in the reference projection will be avoided by taking a combination of several and perhaps all of the measures listed in Table 2 . In addition, taxes may be raised in some countries.

\section{DISCUSSION AND CONCLUSION}

This study confirms findings from previous research that current public pension arrangements in the largest OECD countries are unsustainable in the long run because they rely almost exclusively on pay-as-you-go schemes. Without major reform, rapid population aging will lead to large increases in pension expenses over the next several decades. For example, spending on public pensions in Italy can be expected to require an implausible rise from 35 percent to 75 percent of earnings between 2000 and 2050 in the absence of changes in labor force participation and retirement patterns or in the pension benefit ratio. This huge growth in pension costs is largely attributable to a more than doubling of the number of pensioners per worker from 0.7 in 2000 to 1.5 in 2050 . Very large increases in the expenditure ratio by 2050 are also projected for France (from 29 percent to 54 percent of earnings) and Germany (from 24 to 45 percent). The urgency to act is greatest in these countries because aging is most rapid (owing to low fertility and migration levels), retirement ages are youngest (owing in part to high pension benefits), employment rates are lowest (owing in part to late entry into and early departure from the labor force and generous unemployment benefits), and public pension benefits are highest (owing in part to the absence of employerprovided pensions and private savings). In the English-speaking countries- the United Kingdom, the United States, and Canada - and to a lesser extent in Japan, the future growth in pension expenses, while large, is more manageable because, relative to the large continental European countries, labor force participation and age at retirement are higher, benefits are less generous, and retirees rely to a greater extent on other sources of income.

Reductions in the generosity of future public pensions seem inevitable. To maintain relative standards of living for future retirees requires that other sources of income be found. Many governments are now encouraging the expansion or creation of alternative funded systems in which workers save for their own retirement. Numerous approaches are available for implementing such systems: private or public, mandatory or voluntary, with or without subsidies or tax incentives, employer or personal. The fiscal problems of the current unfunded pay-as-you-go systems would have been avoided if countries had adopted funded systems in the past. Unfortunately, switching now from unfunded to funded systems entails large transition costs. Reallocating a portion of current contributions and investing them in private pensions is possible, but such a diversion would make the fiscal predicament of the public system even more difficult. Governments therefore avoid this approach and instead encourage additional contributions that complement rather than substitute for the public pension program.

Demographic options are generally ignored in the debate about pension reform. Many governments are reluctant to support pronatalist measures because of a disinclination to interfere with personal decisionmaking regarding family size, or because of the apparent 
inconsistency of advocating pronatalism at home while supporting efforts to reduce fertility in poor developing countries; in addition, they may hope that fertility will soon increase again without intervention (Caldwell et al. 2002; Demeny 2003; Gauthier 1996). Furthermore, low levels of recent fertility have not yet led to declines in population size in most developed countries, because the effects of below-replacement fertility have been offset temporarily by modest levels of immigration and population momentum. It seems likely, however, that growing concerns about the implications of population aging will stimulate more interest in efforts to encourage higher fertility directly or indirectly. For example, family-support measures such as subsidized childcare, reduced taxes for families with children, and paid parental leaves are widely acceptable and could be expanded. A recent review of the impact of such measures by Caldwell et al. (2002) concludes that they do raise fertility modestly, provided the subsidies are sufficiently large. This finding is not surprising since on average actual fertility is lower than desired family size, and reductions in the cost of childbearing will make it easier for women to combine a career with their preferred level of childbearing.

The migration option is often considered problematic for social, economic, and cultural reasons. For example, raising the net migration rate in Japan from its current very low level of 0.4 per 1,000 population to 2.9 per 1,000 (which is still lower than the current rate observed in Canada and the United States) for the next half century implies that by 2050 18 percent of Japan's population would consist of new immigrants and their descendants. Such a change in the population composition is and has been acceptable in countries such as the United States, Canada, and Australia, which have experienced high immigration in the past, but it is not welcomed in Japan and parts of Europe.

Despite these concerns, the demographic options can make significant contributions to the goal of creating fiscal equilibrium in public pension systems as part of a comprehensive package of reform. In addition, slower population aging brought about by higher future levels of fertility and migration has other desirable effects that have not been considered here, including lower future health care costs, a larger labor force, and possibly higher living standards (McDonald and Kippen 2001; United Nations 2001; OECD 1998). It therefore seems desirable to pay more attention to the demographic options and to investigate further their cost-effectiveness compared to more conventional measures.

Most governments of OECD countries are cognizant of the challenges posed by population aging, and some reforms aimed at restoring fiscal balance to their pension systems have already been adopted and further changes are planned (Disney and Johnson 2001; Feldstein and Siebert 2002; Jackson 2002). These efforts focus on achieving reductions in future benefits, even though this option is difficult politically because large proportions of pensioners receive most of their incomes from public pensions. In addition, efforts are being considered to encourage later age at retirement by removing incentives to early retirement. Reforms adopted in recent years are generally phased in slowly, thus leaving current pensioners largely unaffected, and their impact will therefore be felt mainly by future retirees. Today's workers will have to save more, work longer, retire later, receive less generous 
benefits, and perhaps pay more taxes. The modest ongoing reforms are a step in the right direction but they are far from adequate.

\section{APPENDIX: DATA SOURCES}

Population. Estimates (1970-2000) and projections (2000-2050, medium variant) of population by age (5-year age groups) and sex as well as total fertility rates and migration rates from United Nations (2003). These data are available online at http://esa.un.org/unpp/.

Employment. Estimates of employment and labor force participation rates by age and sex from 1970 to 2000 from OECD web site http://www1.oecd.org/scripts/cde/. Proportion of total employment that is self-employed from same source.

Earnings. Wages and salaries and GDP from OECD National Account Statistics (OECD 2002b). Self-employed income estimated by assuming that average earnings per self-employed worker equal the average earnings of employees.

Pension expenditures and benefits. Estimates of pension spending as a proportion of GDP in 2000 from OECD (2001b) and Dang et al. (2001). Total benefits in 2000 are assumed to equal total pension expenditures.

Mean age at retirement. Estimated from labor force participation rates by age and sex with method proposed by Latulippe (1996).

\section{NoTES}

1 Estimates of the number of pensioners are not entirely accurate because some retirees may elect to delay accepting benefits or may not qualify for pensions even if they are past the minimum age of eligibility. In addition, some pensioners continue to work while receiving benefits. Estimates of these partly offsetting effects are not readily available, and no effort at correction is made here.

2 The most generous public pension systems tend to be the least redistributive. As a result, variation in generosity of public pensions is reflected primarily in differences in the entitlements of high-income workers. Benefits of poor workers are more similar across countries (OECD 2001a).

3 Employers' public pension contributions are not included in earnings.

4 Administrative costs are another reason why contributions exceed pension expenditures.

5 An alternative indicator of relative benefits is the so-called replacement rate, which compares pensions of retirees with the incomes they received before retirement. Estimates of replacement rates are difficult to obtain because they require income data from household surveys.

6 In addition, no adjustments are made for differences in household composition between pensioners and workers.

7 A similar decomposition of public pension expenditures into four components is presented 
by Dang et al. (2001). The main difference between their decomposition and the one used here is that the former uses GDP rather than earnings in the denominators of the pension expenditure ratio and in the benefit ratio.

A rise in the overall level of labor force participation reduces the number of pensioners because it reduces the number of people under age 65 who are retired and above the minimum age of eligibility for public pensions. This effect is independent of changes in the mean age at retirement or the age of eligibility.

9 Dang et al. (2001) summarize official country projections that include the impact of these reforms, which vary widely in nature and scope among countries. See Jackson (2002) for a criticism of these official projections.

10 Nevertheless, further increases in public pension taxes are planned in Japan and Canada (Jackson 2002).

11 Estimated total fertility rates for 1995-2000 are: Canada 1.6, France 1.8, Germany 1.3, Italy 1.2, Japan 1.4, United Kingdom 1.7, and United States 2.1 (United Nations 2003).

12 Estimated annual net migration rates for 1995-2000 are: Canada 5.1, France 0.7, Germany 2.6, Italy 2.0, Japan 0.4, United Kingdom 2.0, and United States 4.5 (United Nations 2003).

\section{REFERENCES}

Caldwell, John C., Pat Caldwell, and Peter McDonald. 2002. "Policy responses to low fertility and its consequences: A global survey," Journal of Population Research 19(1): 124.

Chand, Sheetal and Albert Jaeger. 1996. "Aging populations and public pension schemes," IMF Occasional Paper Number 147. Washington, DC: International Monetary Fund.

Dang, Thai Than, Pablo Antolin, and H. Oxley. 2001. "The fiscal implications of ageing: Projections of age-related spending," Economics Department Working Paper No. 305. Paris: OECD.

Demeny, Paul. 2003. "Population policy," in Paul Demeny and Geoffrey McNicoll (eds.), International Encyclopedia of Population. New York: Macmillan Reference USA.

Disney, Richard and Paul Johnson. 2001. "An overview," in Richard Disney and Paul Johnson (eds.), Pension Systems and Retirement Incomes across OECD Countries. Cheltenham, UK: Edward Elgar.

Feldstein, Martin and Horst Siebert. 2002. Social Security Pension Reform in Europe. Chicago: University of Chicago Press.

Gauthier, A. H. 1996. The State and the Family: A Comparative Analysis of Family Policies in Industrialized Countries. Oxford: Oxford University Press.

Gruber, Jonathan and David A. Wise. 1999. "Introduction and summary," in Jonathan Gruber and David A. Wise (eds.), Social Security and Retirement around the World. Chicago: University of Chicago Press.

Jackson, Richard. 2002. The Global Retirement Crisis. Washington, DC: Center for Strategic and International Studies. 
Latulippe, Denis. 1996. "Effective retirement age and duration of retirement in the industrial countries between 1950 and 1990," Issues in Social Protection, Discussion Paper 2. Geneva: International Labour Office, Social Security Office.

McDonald, Peter and Rebecca Kippen. 2001. "Labor supply prospects in 16 developed countries, 2000-2050," Population and Devlopment Review 27(1): 1-32.

OECD. 1998. Maintaining Prosperity in an Ageing Society. Paris: OECD Publications.

- 2001a. Ageing and Income: Financial Resources and Retirement in 9 OECD Countries. Paris: OECD Publications.

- 2001b. "The fiscal implications of ageing: Projections of age-related spending," OECD Economic Outlook, June.

- 2002a. "Increasing employment: The role of later retirement," OECD Economic Outlook, December.

- 2002b. National Accounts of OECD Countries: Main Aggregates 1970/2000, 2002 Edition, Volume I (CD-ROM Windows). Paris: OECD Publications.

United Nations. 2001. Replacement Migration: Is It a Solution to Declining and Ageing Populations? New York: United Nations.

- 2003. World Population Prospects: The 2002 Revision. New York: United Nations Population Division. Estimates (1950-2000) and projections (2000-2050), medium variant, are also available at http://esa.un.org/unpp/

World Bank. 1994. Averting the Old-age Crisis: Policies to Protect the Old and Promote Growth. Oxford: Oxford University Press. 


\section{POLICY RESEARCH DIVISION WORKING PAPERS}

If still in print, single copies of up to three working papers from 1989 through 2003 are available free of charge.

Beginning with the 2004 issues, the working papers will no longer be available in print format. Instead they will be distributed electronically. As each new paper is completed subscribers will be notified by e-mail and a link to the paper will be provided.

To subscribe to the Policy Research Division working paper e-mail notification list, or to obtain back issues from 1989 to 2003, please send your request to prdwp@popcouncil.org.

PDFs of recent issues are available at www.popcouncil.org/publications/wp/prd/rdwplist.html

2004

185

John Bongaarts, "Population aging and the rising cost of public pensions."

184 Mark R. Montgomery and Paul C. Hewett, "Urban poverty and health in developing countries: Household and neighborhood effects."

\section{3}

183 Agnes R. Quisumbing and Kelly Hallman. "Marriage in transition: Evidence on age, education, and assets from six developing countries."

182 Paul C. Hewett, Barbara S. Mensch, and Annabel S. Erulkar, "Consistency in the reporting of sexual behavior among adolescent girls in Kenya: A comparison of interviewing methods."

177 John Bongaarts, "Completing the fertility transition in the developing world: The role of educational differences and fertility preferences."

*No longer available as a printed publication. Download electronic file from Web site only. 
176 Cynthia B. Lloyd and Paul C. Hewett, "Primary schooling in sub-Saharan Africa: Recent trends and current challenges."

175 James F. Phillips, Tanya C. Jones, Frank K. Nyonator, and Shruti Ravikumar, "Evidence-based development of health and family planning programs in Bangladesh and Ghana."

174 Geoffrey McNicoll, "Population and development: An introductory view."

173 Paul Demeny, "Population policy: A concise summary."

172 Zachary Zimmer, Napaporn Chayovan, Hui-Sheng Lin, and Josefina Natividad, "How indicators of socioeconomic status relate to physical functioning of older adults in three Asian societies."

171 Sajeda Amin and Nagah H. AlBassusi, "Wage work and marriage: Perspectives of Egyptian working women."

170 Ravai Marindo, Steve Pearson, and John B. Casterline, "Condom use and abstinence among unmarried young people in Zimbabwe: Which strategy, whose agenda?"

169 Zachary Zimmer and Julia Dayton, "The living arrangements of older adults in sub-Saharan Africa in a time of HIV/AIDS."
168 Paul C. Hewett, Annabel S. Erulkar, and Barbara S. Mensch, "The feasibility of computerassisted survey interviewing in Africa: Experience from two rural districts in Kenya."

2002

167* Dominic K. Agyeman and John B. Casterline, "Social organization and reproductive behavior in southern Ghana."

166* Carol E. Kaufman and Stavros E. Stavrou, “'Bus fare, please': The economics of sex and gifts among adolescents in urban South Africa."

165 Kelly Hallman, Agnes R. Quisumbing, Marie Ruel, and Bénédicte de la Brière, "Childcare, mothers' work, and earnings: Findings from the urban slums of Guatemala City."

164 Cynthia B. Lloyd, Cem Mete, and Zeba A. Sathar, "The effect of gender differences in primary school access, type, and quality on the decision to enroll in rural Pakistan."

163 Barbara S. Mensch, Wesley H. Clark, and Dang Nguyen Anh, "Premarital sex in Vietnam: Is the current concern with adolescent reproductive health warranted?"

162 Naomi Rutenberg, Carol E. Kaufman, Kate Macintyre, Lisanne Brown, and Ali Karim, "Pregnant or positive: Adolescent childbearing and HIV risk in South Africa."

*No longer available as a printed publication. Download electronic file from Web site only. 
161 John Bongaarts, "The end of the fertility transition in the developing world."

160 *Julia Dayton and Martha Ainsworth, "The elderly and AIDS: Coping strategies and health consequences in rural Tanzania."

159 Carol E. Kaufman, Shelley Clark, Ntsiki Manzini, and Julian May, "How community structures of time and opportunity shape adolescent sexual behavior in South Africa."
158 Geoffrey McNicoll, "Demographic factors in East Asian regional integration."

157 Zachary Zimmer and Sovan Kiry Kim, "Living arrangements and socio-demographic conditions of older adults in Cambodia."

156 John Bongaarts and Griffith Feeney, "How long do we live?"

155 Zachary Zimmer, Linda G. Martin, and Ming-Cheng Chang, "Changes in functional limitations and survival among the elderly in Taiwan: 1993, 1996, and 1999."

*No longer available as a printed publication. Download electronic file from Web site only. 